Immigration and the New Politics of Inclusion and Exclusion in the European Union: The Effect of Elites and the EU on Individual-Level Opinions Regarding European and non-

\title{
European Immigrants*
}

Lauren M. McLaren

\author{
Department of Political Science and Public Administration \\ Bilkent University \\ 06533 Bilkent \\ Ankara, Turkey \\ lauren@bilkent.edu.tr
}

* Paper presented to the Workshop on Citizenship, Political Mobilisation and Ethnic Minorities: Comparative and Integrated Studies at the ECPR Joint Sessions, Mannheim, 26-31 March 1999. The author would like to thank Mark Franklin and Meltem Müftüler-Baç for their very helpful comments on this paper. 


\title{
Immigration and the New Politics of Inclusion and Exclusion in the European Union: The Effect of Elites and the EU on Individual-Level Opinions Regarding European and non- European Immigrants*
}

\begin{abstract}
Within European politics, a distinction is currently being made at the elite level between internal and external immigration, with individuals from EU countries being given special rights and privileges when they migrate within the EU. This paper addresses the question of whether individual EU citizens also view the two types of immigrants differently and what structures their beliefs regarding these two sources of migration. The findings indicate that (a) the vast majority of EU citizens view internal and external migration as identical, (b) elite cues and debates regarding immigration within each of the countries are helping individuals form their opinions regarding the two different types of immigration, and (c) hostility toward external migration is racially motivated while hostility toward internal migration is nationalistically motivated. These findings and their implications are discussed in the body of the paper.
\end{abstract}


Over the last several years, the issue of immigration has come to dominate the policy agendas of West European countries, as well as the institutions of the European Union. Besides the issues of national security and defence, external immigration (i.e., immigration from outside of the EU) is the main problem raised when EU member state leaders discuss the possibility of further political integration, and external immigration is the specific reason for the still-existent barriers to the free movement of people within the EU. In many of the member states, high levels of immigration appear to have produced an increase in hostility toward immigrants (Quillian 1995; McLaren 1996b), increased support for right-wing parties (Knigge 1998; LewisBeck \& Mitchell 1993), and even produced violent right-wing behavior (McLaren 1999). While many member states (e.g., Germany) seemed to hold their breath for quite some time before readjusting their immigration and immigrant policies, it is simply no longer possible to ignore this issue. ${ }^{1}$

Within European politics, a subtle distinction is currently being made between individuals who migrate from within the EU and those who come from outside the EU. One of the goals outlined in the 1957 Treaty of Rome (in particular, the European Economic Community Treaty $)^{2}$ was the free movement of people for the purposes of work and travel within the entirety of the European Economic Community. By the early 1980s, this goal had still not been achieved - passport controls were still in place and native workers were given preferential treatment in hiring, firing, and social services associated with employment—and this failure (along with other physical barriers to trade) eventually led to the adoption of the Single European Act in $1986 .^{3}$ However, the question of the treatment of migrants from within the EC was only partially addressed at this point. Finally, the Treaty on European Union (ratified in 1993) dealt specifically with citizenship issues, and individuals who were citizens of one EU country but

\footnotetext{
${ }^{1}$ See Hammar (1985) on the distinction between immigrant and immigration policy.

2 There were actually two Treaties of Rome: the EEC Treaty and the Euratom Treaty.

${ }^{3}$ See Cameron (1991) for a review of these barriers to free trade.
} 
who had taken up residence in another EU country were given the right to vote and run as candidates in local and EU-level elections (not in national elections, though). ${ }^{4}$ This is a fairly major milestone in the development of the notion of an European citizenship. Of course, no such citizenship provisions were granted to migrants who came from outside of the EU, in great part because the treatment of external immigrants is still within the domain of domestic politics (although the recently ratified Treaty of Amsterdam indicates that EU countries will try to coordinate policy regarding one form of external migration - asylum seekers). One possible implication of the fact that national governments readily granted political rights to other EU citizens is that, among elites, there is a fairly clear distinction between EU-migrants and non-EU migrants, namely that EU citizens should have special privileges when they decide to move to another EU country whereas other migrants should not.

The primary question that is addressed here is whether citizens of the EU take the same perspective - do they see a clear distinction between other Europeans migrating to their countries and non-Europeans doing the same? In other words, are they responding to elite cues in predictable ways? Past research on the EC strongly indicates that national/party elites have been leading public opinion regarding European integration (Inglehart 1970; Wessels 1995; Gabel 1998). The current research attempts to discover whether this elite leadership of public opinion has manifested itself in the specific issue of migration by comparing public opinion regarding external (i.e., outside the EC) and internal (inside the EC) migration. If elites are indeed leading the way in opinion formation, we would expect the process to be different for the two different types of immigration. This hypothesis is further elaborated below.

The findings indicate that there are two basic types of Europeans in the realm of immigration: one who would grant other Europeans more freedom of entry and another who sees

\footnotetext{
${ }^{4}$ See Martiniello (1995) for a review of the other provisions for citizenship in the Maastricht Treaty, as well as an excellent criticism of these provisions.

Also, see Dinan (1994) or Urwin (1995) for summaries of these events.
} 
European migrants as identical to non-European migrants. The next step in the analysis is the examination of attitudes toward the two different types of immigration-external and internal migration - to determine (a) whether these attitudes appear to be responding to elite cues in predictable ways and (b) whether attitudes toward the two types of immigration are structured similarly.

\section{The Extent of the Divide}

Before moving on to analyse the predictors of attitudes toward internal and external immigration, it is necessary to explore responses to survey questions about immigration. The following questions were asked in the countries of the EC in Eurobarometer 39.0 (Spring 1993): ${ }^{5}$

* If people from different countries of the South of the Mediterranean wish to work here in the European Community, do you think they should: 1. Be accepted, without restrictions, 2. Be accepted, but with restrictions, 3. Not be accepted, 4. Don't know.

* And what about people coming from other countries of the European Community who wish to settle in (OUR COUNTRY)? Do you think that they should 1. Be accepted, without restrictions, 2. Be accepted, but with restrictions, 3. Not be accepted, 4. Don't know.

What are Europeans' perspectives on allowing other Europeans into their country, when compared to the entry of non-Europeans? Is it true that ". . . within Europe, there is now a widely held view of cultural closeness and similarity between all the 'nations' of Western Europe ..." (Thränhardt \& Miles 1995, 10)? There does appear to be some degree of preference for EC migration in every EC country-more respondents would allow EC citizens to migrate with no

\footnotetext{
${ }^{5}$ Since the Treaty on European Union had not yet been ratified (and had not taken effect), the entity now called the European Union was still named the European Community at the time of the survey.
} 
restrictions to their countries than would allow South-of-the-Mediterranean migrants the same treatment. Additionally, fewer respondents would outright reject EC migrants than are willing to reject migrants from South of the Mediterranean (Table 1, first 4 columns).

[Table 1 about here]

Table 1 (columns 5 and 6) also provides a breakdown of the percentages of individuals who gave identical responses to questions about European and non-European immigrants and those who gave a more favourable response to the question about EC immigrants. ${ }^{6}$ This portion of the table addresses the question of how "widely held" this cultural affinity actually is. The percentages illustrate that in every country except Denmark, clear majorities gave identical responses to questions about immigrants from South of the Mediterranean and immigrants from the EC. ${ }^{7}$ Thus, while the visionaries within the European Union may have notions of creating an European citizenship and believe that citizens of one European country feel an affinity with other Europeans, the percentages only indicate some degree of preference for EC migrants, with most individuals appearing not to make a distinction between EC and non-EC migrants. ${ }^{8}$

Also, the data for this analysis were obtained through the Interconsortium for Political and Social Research at the University of Michigan.

${ }^{6}$ Individuals who fit into the latter group are those who would (a) not accept non-EC immigrants but would either accept EC immigrants with restrictions or with no restrictions or (b) would accept non-EC immigrants with some restrictions but would accept EC immigrants with no restrictions.

${ }^{7}$ The author realises that by 1993 West Germany and East Germany were no longer separate countries. However, because of the different socialisation of eastern and western Germans, the two samples will be kept separate.

${ }^{8}$ The author acknowledges that the centre category_- "accepted, but with restrictions"-is somewhat vague and allows respondents to maintain ambiguous positions on both types of immigration. However, it was expected that, with the movement toward greater European unification, Europeans would be much more ready to allow other Europeans free entry into their countries. However, the findings indicate that EU citizens mostly wish to restrict all types of migration to some degree. (The percent who would grant entry to all immigrants is fairly small, ranging from five percent in Denmark to 23 percent in Spain.) 
The main question raised by these percentages is: what explains the differences in opinions regarding the two type of immigrants and are these opinions responding predictably to elite cues?

\section{Elite Opinion Leadership}

The main hypothesis of interest here is that elites have considerable influence over individuals' attitudes regarding the two types of immigration. This theoretical approach has its foundation in the classic work of Converse (1964) and the more recent work of Zaller (1990, 1991, 1992). Converse (1964) argued that individual citizens are likely to be following elite cues regarding what issues are supposed to go together in an organised belief system, and while he did not find much of an organised belief system in his early work, he later discovered that the more attentive portion of the masses do tend to resemble the elites (Converse 1975). Similarly, Zaller argues that if the messages coming from all political parties and political elites are supportive of a particular policy, then politically aware individuals will come to incorporate these preferences into their own belief systems. If, on the other hand, the messages are conflicting along partisan lines, then the individual's own partisan values will influence his or her acceptance of messages.

Additionally, research specifically on the EC has shown that individual-level support for that institution follows the cues of national elites (Inglehart 1970; Janssen 1991; Wessels 1995; Gabel 1998). Specifically, the cognitively mobilised individuals are argued to be more supportive of the EC, in great part because they are following elite cues regarding the EC, which have been mostly positive (Inglehart 1970; Janssen 1991; Gabel 1998). From Zaller's (1990, 1991, 1992) work, we could infer that with mostly positive elite cues, the attentive masses will

also take a positive attitude regarding the EC. Finally, Wessels' (1995) research illustrates that party leadership effects attitudes regarding the EC. 
If political elites are truly playing a key role in formulating mass attitudes, what behavioural manifestations of such a phenomenon would we expect to observe in the realm of internal and external migration?

\section{Cognitive Mobilisation}

First, the more cognitively mobilised individuals are likely to be supportive of internal migration, but no more or less supportive of external migration. The reason for this expected difference revolves around the nature of elite debate regarding the two types of immigration. Elites have been mostly consensual and positive on their countries' participation in European integration (Inglehart 1970; Bogdanor 1986, 1989 Franklin, Marsh \& McLaren 1994; van der Eijk \& Franklin 1996; Gabel 1998), and since the more attentive portion of the public tends to follow these elite cues, they are likely to be more supportive of European integration. Indeed, cognitive mobilisation has been shown to be related to an individual's degree of support for the EU (Janssen 1991; Gabel 1998; Gabel \& Palmer 1995). Specifically, individuals who talk about politics more frequently (the conceptualisation utilised by Gabel 1998 and Gabel \& Palmer 1995) tend to have more favourable attitudes toward the EU; those who do not spend much time discussing political matters are more hostile toward the EU. The argument in the current research is that this effect of elites on general support for the EU has carried over to the realm of internal migration and is leading individuals who are cognitively mobilised to support this specific element of European integration. Additionally, the provision of privilege for EU citizens was one of the elements included in the Maastricht Treaty, which was debated widely before its ratification, and it seems that the more attentive individuals are likely to be more aware of this provision and more supportive of it (again, as a result of following elite discussion on the issue).

On the other hand, elite cues regarding external migration are far from consensualelites in Europe are quite divided on how to handle immigration and immigrants, with parties of 
the right often advocating stricter immigration laws than parties of the left (see the discussion below). Thus, we expect cognitive mobilisation to matter more in determining attitudes toward internal, EC migration than external, non-EC migration because of this lack of elite consensus (and, therefore, lack of unified elite cues) on issues of external migration and the existence of an elite consensus on the EC.

\section{Ideology}

Many researchers argue that the left-right scale serves as a summarising device for individuals in West European countries (see, for instance, Inglehart \& Klingemann, 1976, 1979; Franklin, Mackie, Valen, et al. 1992; Knutsen 1998), and others have found this scale to be related to attitudes toward external migration (see Hoskin 1991; McLaren 1996a, 1996b). Generally, individuals on the left appear to be more open to changes in society, including the addition of new immigrants, whereas those on the right are more hostile to such changes. In the realm of external migration, national-level elites are also providing important cues to the followers of their ideology regarding their opinions toward immigrants and immigration. For instance, in France, the Socialists traditionally called for increased protection of immigrant rights, and even proposed local voting rights for immigrants (but later dropped the proposal), while the mainstream right-wing parties were clearly quite hostile toward immigration. Jacques Chirac, leader of the Rally for the Republic Party once spoke of the French worker who lives next door to an immigrant family " "with a father, three or four wives, some 20 children, that receives 50,000 francs per month in social welfare, obviously without working . . . Add to that the noise and the smell, and the French worker goes crazy' " (quoted in the New York Times, 23 June 1991). Similarly, Charles Pasqua, former neo-Gaullist Minister of the Interior once said "France has been a 'country of immigration,' but it no longer wishes to be one" (see Hollifield 1994). Similar statements from parties of the right can be found in other European countries, 
with parties of the left tending to take a more permissive view of immigration and immigrant rights. $^{9}$

How will left-right self-placement affect attitudes toward internal migration, though? On the one hand, if the reason that the right tends to reject external migration is because of fear of changes in society, then the right might also oppose internal migration, as EU migrants threaten to change the composition of the nation just as much as external immigrants. On the other hand, since national elites have been mostly consensual with regard to the EU (see van der Eijk \& Franklin 1996; Franklin, Marsh, McLaren 1994; Bogdanor 1989, 1986), citizens may not be divided by left-right self-placement on the issue. In other words, with regard to external migration, elites in many countries have tended to divide across parties (with parties of the left supporting freer immigration and immigrants' rights and parties of the right favouring stricter immigration and immigrant policies), providing divisive cues to their followers; with regard to internal migration (and the EU), elites have mostly been supportive, and there are few divisions among them over the EU (and thus internal migration). Therefore, it is likely that left-right selfplacement will matter more in determining attitudes toward non-EC migrants than in determining attitudes toward migrants from within the EC.

\section{Education}

Like the cognitively-mobilised, better-educated individuals are likely to be following debates/discussions regarding the EU and migration (see Inglehart 1970). If elites are truly leading opinion, a prerequisite to education having an effect on attitudes toward either type of

\footnotetext{
${ }^{9}$ The very recent proposal by the Social Democrat/Green coalition in Germany to make the naturalization process easier (and thereby allow non-Germans easier access to German citizenship) is a good example of this debate on immigration issues - after the proposal by the left, the Christian Democrats immediately began criticizing it, arguing that the Social Democrats were threatening to make Germany a playground for multiculturalism. Similar debates have occurred in France, for instance, when the late president Mitterand proposed allowing local-level voting rights for immigrants. The proposal was dropped quickly after criticism from the right.
} 
migration is that there has been elite discussion/debate on these issues. More specifically, countries which have a long history of external immigration (because of labour recruitment or because of their former colonial experience) have also experienced more "problems" of immigration and more public discussion of potential solutions. The EC countries that have long modern histories of external immigration are France, Belgium, the Netherlands, Britain, Germany, and Denmark (see Cornelius, Martin, \& Hollifield 1994 for a general summary of the history of immigration to Western Europe). Thus, better-educated individuals in these countries are likely to have different opinions than the less educated because they are paying more attention to this discussion. In the other EC countries, the more and less educated are likely to be very similar in their opinions regarding external migration because of a lack of debate which could be followed (which, in turn, results from a lack of an "immigration problem").

With regard to attitudes toward internal migration, it is expected that educated individuals in all EC countries will be more supportive of this type of immigration than lesseducated individuals. Discussion of the European project had been going on for approximately 40 years in most of these countries, and even the later admittees had been preparing to join the Common Market for quite some time when they were finally admitted. Thus, elite discussion of the process of completing the Common Market has occurred in every EC country. Apparently, paying attention to this elite discussion and explanations for the necessity of a single European market leads individuals to be generally supportive of the European project (Inglehart 1970; Anderson \& Reichert 1996; Gabel 1998), which should, in turn, lead to support for this specific proposal of allowing EC citizens to freely migrate within the geographical space of the EC.

\section{Support for the EC}

As just stated, general support for the EC should translate into support for the specific issue of internal migration. The problem of the free movement of people within the EC has been 
discussed among national and EC officials since the formation of the EEC, and so those people who generally support the EC should also support this particular element of completing the single market. On the other hand, the EC is not expected to provide such a positive cue to attitudes toward external migration. At the time of the survey used in this research, the EC still had not developed a coherent external migration policy, so citizens are not likely to be taking cues from the EC about external migration.

It should be noted, however, that it is possible that in some countries, arguments made in favour of internal migration may also be consistent with support for external migration, if the arguments are couched in general terms-for instance, one argument that supports the idea of free internal migration is that it will help keep labour costs down, but this argument also supports the idea of free external migration. Nevertheless, support for internal migration should generally be higher among those who believe their country has benefited from EC membership.

\section{Analysis Method and Control Variables}

In order to be able to simultaneously estimate the effects of all the above variables, regression analysis was used, with separate analyses for each country. On the dependent variable, 'don't know' was recoded to appear in the middle of what became a four-point ordinal scale. Coding of the independent variables is described in the appendix. By analysing the data separately for each country, the research findings are subjected to what are essentially twelve separate replications, which allows for the testing of cross-national differences in attitudes regarding migration.

So as to ensure a well-specified model, it seemed important to control for certain other concerns that have been found relevant in previous research about attitudes towards immigrants. In U.S. studies, it has been argued that people in precarious financial situations are likely to be most hostile towards immigrants because of a concern that immigrants might take their jobs 
(Citrin et al. 1997), which is based on the self-interest literature (cf. Citrin, Reingold, \& Green 1990; Kinder \& Sears 1981; Lau, Brown, \& Sears 1978; Sears et al. 1978; Sears, Hensler, \& Speer 1977). Previous research in Europe has not found that the individual's financial situation, unemployment status, etc. have much effect on attitudes regarding immigrants (Quillian 1995; McLaren 1996a, 1996b), but it still seems important to include potentially relevant controls.

Blatant prejudice is another orientation that, where present, will make people reluctant to accord rights of admission to immigrants (Allport 1954). And finally, postmaterialism (interpreted as a set of attitudes that favor democratic norms and procedures - see McLaren 1996a, 1996b) should also be taken into account (cf. Inglehart 1990).

\section{Findings}

\section{Cognitive Mobilisation}

First, cognitive mobilisation (political discussion) is relevant in more countries in predicting attitudes toward internal migration than in predicting attitudes toward external migration (compare Tables 2 and 3). People who discuss politics frequently are more likely to support internal migration in France, the Netherlands, western Germany, Denmark, Britain, and Greece, whereas people who discuss politics more frequently are more open to external migration only in the Netherlands and western Germany. Additionally, the relationship is not quite as strong in the latter cases as in the former. The implication of these findings is that since national elites have a more consensual opinion regarding the EC than they do regarding external migration, people who discuss politics frequently have picked up on these positive cues, making them more supportive of EC policy, including free migration for EC citizens. As mentioned 
above, elite discussion of external migration is far from consensual, the cues are not clear, and thus, the cognitively mobilised are also not as consensual about this issue. ${ }^{10}$

[Tables 2 and 3 about here]

\section{Ideology}

As predicted, left-right self-placement appears to matter mostly in determining attitudes toward external migration, with leftists having less restrictive attitudes, and people on the right taking a more restrictive view. This is not the case with internal migration, however-left-right self-placement appears not to matter in most countries, and where it is important, the relationships are weaker than is the case with external migration. Again, this very likely reflects the cues of the national elites: leaders on the right and left have tended to be generally supportive of the European project, but have often taken very different stances on external migration. The findings in many countries appear to reflect these elite differences in statements regarding the two issues (the EU/internal migration versus external migration).

The Effect of Ideology: A Critical Test. If elite debate is structuring citizen attitudes regarding immigration, we would expect this to occur mostly in countries where elites and parties have been divided over immigration along the left-right continuum. Indeed, it is not the case that leftright self-placement is an equally strong and significant predictor of attitudes regarding external migration in all EU countries, and the differences appear to be based on how divisive the national parties have been on the issue of external immigration. According to expert assessments

\footnotetext{
${ }^{10}$ While the Adjusted R-squared figures in Tables 2 and 3 may appear low, they are actually quite normal for Eurobarometer data. One other piece of research reported R-Squared values as low as .03 on a study of support for European integration (Anderson and Reichert 1996). Other research on a similar topic finds RSquareds ranging from .07 to .16 (Gabel 1998; Gabel and Palmer 1995). Finally, the R-Squareds from
} 
collected by Huber \& Inglehart (reported in Huber \& Inglehart 1995), xenophobia has become an important element dividing parties of the left from those of the right in France, Belgium, and Germany. ${ }^{11}$ If parties are truly leading their followers in opinion formation regarding external immigration, an additional expectation is that in the countries where immigration has actually been shown to divide the parties, the relationship between individual-level left-right selfplacement and hostility toward external migration will be stronger than in countries where party leaders have not been quite so divisive over immigration.

A t-test was conducted to compare the unstandardised coefficients for left-right selfplacement (which appear in Table 2) for the countries where xenophobia divides left from right to some degree and those countries where it does not divide parties. The results indicate that the difference between the two groups of coefficients is statistically significant. On average, the leftright effects on attitudes toward external immigrants for the group of countries where xenophobia does divide parties along left-right issue space is -0.0575 , whereas the average $b$ coefficient for the rest of the countries is -0.027 , and this difference is significant at the .01 level. Although the difference (and indeed the coefficients) seem small, that level of significance is quite impressive, considering that the number of observations in this meta-analysis is only $13 .{ }^{12}$

Moreover, Knutsen (1998), in a reanalysis of the Huber-Inglehart data, reports the percentage of experts who claim that xenophobia is an important issue dividing parties along the left-right continuum in each of the EC countries. These figures are listed in Table 4, with “*” indicating whether the left-right coefficient was significant in each of the countries. On average,

research on support for the European Court of Justice, where the sample was even reduced to only those respondents who are aware of the Court, range from .07 to .19 (Gibson and Caldiera 1995).

${ }^{11}$ Experts were asked about several different categories of issues that might be important in dividing the left from the right, and one of these categories was labelled "xenophobia." The specific guidelines given to experts stated that xenophobia should be considered an important dividing issue if parties have used the following expressions: "religious/ethnic chauvinism, racism, xenophobic, anti-Semitic, anti-emancipation, primordial appeals, white, black, intolerance, minority rights, black nationalism, immigration, asylum, migration, exclusion of foreigners" (Huber and Inglehart 1995, Table 1).

${ }^{12}$ Luxembourg was excluded from this analysis due to lack of information regarding the importance of xenophobia in national politics. 
in countries where the left-right coefficient was significant, 12.5 percent of experts claimed that xenophobia was important in dividing parties on the left and right, whereas in places where the left-right coefficient was not significant, only one percent of experts claimed that xenophobia was an important divisive issue. This difference is significant at the .01 level.

[Table 4 about here]

The primary conclusion to be drawn from this meta-analysis is that the elite (party leader) cues appear to be important in determining citizens' attitudes toward external immigrants and immigration. In countries where the elites are not divided along the left-right continuum on the issue of external immigration, citizens mostly do not appear to be divided in terms of the leftright spectrum either, but where elites do divide along left-right issue space on the external immigration issue, citizens divide in similar ways.

\section{Education}

As expected, the findings for the relationship between education and support for migration appear to reflect, at least in part, the history of immigration in each of these countries. Specifically, there is a significant, positive relationship between education and support for external migration in France, Belgium, the Netherlands, Britain, eastern Germany, and Denmark. With the important exception of western Germany, these are all of the countries in the EU that have experienced considerable external migration, from their former colonies and from the recruitment of foreign labour (for an excellent summary of immigration to Western Europe, see Cornelius, Martin, \& Hollifield, 1994).

Why should education matter in determining immigration attitudes only in contexts where there is a long history of immigration? Drawing from the literature on political tolerance, 
individuals with more education seem to understand/believe that excluding certain individuals and groups from participating in the polity is against the norms of democracy (Stouffer 1955; Nunn, Crockett \& Williams 1978; Sullivan, Piereson \& Marcus 1982; Bobo \& Licari 1989). Even though immigrants are (in most countries) not officially part of the polity (i.e., they have very few political rights), more-educated individuals may experience more confusion about who should be excluded and who should be included in the political system. In countries with longer histories of immigration, there has also been a longer history of debate about the inclusion and exclusion of certain groups, and the more-educated individuals are likely to have followed this debate (and indeed participated in it), and in the process of discussing how immigration fits with the norms of democracy, may have determined that restricting immigration is inconsistent with these norms.

The German exception to these findings deserves comment. Over the past 10 years, western Germany has received the largest number of immigrants compared to the rest of Europe (as a proportion of the total population, however, Belgium and the Netherlands have received similar percentages of migrants), and thus one would expect the same debate to have occurred in West Germany, just as in France, Britain, etc. The main difference, however, is that elite discussion of immigration in western Germany has likely stifled mass discussion, and so it is not surprising that individuals at different levels of education have similar opinions about immigration. Specifically, West German leaders proclaimed over and over again that "Germany is not a country of immigration." In that country, more than the others, leaders and citizens held onto the notion that the foreign workers would eventually return home. Since permanent migration was not considered part of the German experience, there was no need for a debate about immigration policy. In other words, if there is no immigration, then there is no need for 
immigration policy, and thus no need to discuss an immigration policy (see Esser \& Korte 1985; Martin 1994). ${ }^{13}$

With regard to internal migration, the places where education appears to be important in determining these attitudes are: France, Belgium, the Netherlands, Britain, Italy, Greece, Spain, Ireland, and Northern Ireland. Thus, in almost every country, the more educated are supportive of internal migration, again, very likely reflecting the debate which has occurred regarding the EC in these countries. (In other words, the more-educated, like the cognitively mobilised, are more likely to have been following the elite debate regarding the EC and internal immigration, which was mostly supportive of this form of immigration.)

One interesting group of countries worth pointing out are those where education is important in determining attitudes toward internal migration, but not external migration. These are: Italy, Greece, Spain, Ireland, and Northern Ireland. These cases are interesting because none of them are countries of high immigration (although some were becoming more popular destination countries at the time of the survey). This confirms our earlier supposition about the importance for attitude formation of political debate. It is likely that the education-immigration relationship in these countries reflects the lack of debate about the issue of external immigration there (since there has not been much external immigration in these countries) in contrast to the salience of issues relating to the European Community, as well as the issues surrounding the completion of the Common Market in these countries.

\section{Support for the EC}

In every country, feeling positive about the EC tends to produce more favourable attitudes toward EC immigrants, indicating that the institution of the EC is providing an

\footnotetext{
${ }^{13}$ It should be noted that this was the official German perspective on immigration until very recently and that the new government is attempting to change German citizenship laws, openly acknowledging that Germany is a country of immigration.
} 
important cue to individuals about how they ought to view migration by other EC citizens. At the same time, however, favourable orientations toward the EC also go with a more positive view of external migration in eight of the samples. Thus, it seems that individuals who favour the EC's goal of opening up the labour market within Europe may see great value in opening the labour market to non-European workers as well. After all, one way to keep product prices low is to hire workers at low wages, and since non-Europeans will often work at lower wages than Europeans, prices will be even lower than they would if non-Europeans could not be hired freely.

\section{Control Variables}

Household financial situation appears mostly irrelevant in predicting attitudes toward immigrants. This is consistent with past research on immigration attitudes (see Quillian 1995; McLaren 1996a, 1996b).

It is somewhat surprising that individuals with postmaterial values do not appear to be any more supportive of migration (internal or external) than those with material values in most of the EC countries. This finding is inconsistent with past research regarding attitudes toward external migration (see McLaren 1996a, 1996b), as well as findings with regard to the EC (see Inglehart 1977). A small cottage-industry of literature arguing against the notion of postmaterialism and/or the measurement of the concept has developed (see Duch \& Taylor 1993; Clarke \& Dutt 1991; Flanagan 1987), and the findings here once again call into question the stability of the concept and measure. Specifically, postmaterialism was found to be very strongly related to attitudes toward external migration (again, see McLaren 1996a, 1996b) using earlier Eurobarometer surveys (as well as very similar controls), and it was found to be strongly related to support for the EC (Inglehart 1977; but see Janssen 1991). The fact that these same findings are not being supported in this survey indicates that either this survey is unusual or that the concept/measure is unstable over time. 
Not at all surprisingly, those individuals who profess to be "disturbed" by individuals of different races and nationalities are more hostile toward immigration than those who claim to be undisturbed. More specifically, individuals who are disturbed by other races tend to be more hostile toward external immigration, whereas those who are disturbed by other nationalities are more hostile toward internal migration. In all but four countries we see significant effects of "disturbed by race" in Table 2, but in Table 3, only five of the countries have significant effects for this variable. The results from "disturbed by nation" are not quite as clear, but they indicate that in one-half of the samples, those who are disturbed by other nations (or who 'don't know') are hostile toward South-of-the Mediterranean immigrants (see Table 2), but in nine of the countries, individuals who claim to be disturbed by other nationalities (or who 'don't know') are hostile toward EC migrants (see Table 3).

Most likely, this is a result of peoples' understanding of the terms "race" and "nation." Race usually refers to the physical characteristics of individuals (see Hobsbawm 1990 for a discussion of race and ethnicity), and, thus, Europeans are very likely seeing external migrants as having different physical characteristics than their own. Some of these individuals, in turn, appear to reject external immigration as a result of feeling disturbed by people who have different physical characteristics. "Nation," on the other hand, often refers to a broader concept which sometimes includes shared physical characteristics, but seems to focus more on shared history, language, culture, and, perhaps religion (again, see Hobsbawm 1990), and it appears that EC citizens may be fearful of other Europeans migrating to their countries because of these cultural differences rather than perceived physical differences.

Finally, feeling disturbed by individuals of other religions also predicts hostility toward both types of migration in a few of the countries. For instance, in France, Belgium, West Germany, East Germany, and Greece, individuals who are disturbed by other religions are more hostile toward external migration (see Table 2), most likely reflecting the fear of the Muslim 
religion brought by Algerians, Turks, and Albanians. Similarly, in France, Ireland, Britain, and Portugal, individuals who are disturbed by other religions tend to be hostile toward internal migration, and in the Netherlands and Denmark, those who "don't know" whether they are disturbed by other religions are also more hostile toward internal migration (see Table 3). Thus, in addition to being racially and nationalistically motivated, hostility toward both types of migrants appears to be partly based on fear of different religions.

\section{Discussion and Conclusions}

What implications can be drawn from the above analyses? First, in terms of raw percentages, the EC does not appear to have created overwhelming feelings of "Europeanness," in that most citizens in EC countries view external and internal migration identically. In other words, most people do not see the need to treat EC citizens with any degree of privilege compared to migrants from outside the EC. The visionaries within the EU have some way to go still in creating feelings of being part of an European project which includes the free movement of labour. However, there is a large minority of EC citizens who do wish to treat internal migrants favourably. Thus, it is likely that national and EC elites have had some effect in teaching citizens about the positive aspects of the European project.

Further evidence was found in support of the notion that the EC and national elites may be leading the way in establishing new norms regarding preferences for different types of immigration. That evidence is that the more attentive portion of the population (which also tends to be more supportive of the EC) has more favourable attitudes toward internal migration but not external migration. The elite discussion about issues of European citizenship are likely to be filtering down to this attentive portion of the mass public, but the lack of clear, cohesive discussions of external migration means that attention to politics does not affect attitudes toward external migrants. Furthermore, individuals who are supportive of the European project are 
consistently more likely to support internal migration, but the findings with regard to their attitudes toward external migration are less consistent.

The discussion here has focused a great deal on the role that elites are playing in moulding attitudes toward various types of immigrants, and the findings with regard to the effect of left-right self-placement add support to the notion that elites really are leading the way in this area. Specifically, the fact that left-right self-placement matters more in determining attitudes toward external migration than in determining attitudes toward internal migration reflects the debate/divisions on the issue of external immigration among national elites and the lack of debate/divisions on the issue of the EC and internal migration among these same elites. Furthermore, the countries where there are elite divisions on immigration are precisely those where left-right divisions structure citizen attitudes toward external migration the most.

Beyond these cues, education also seems to be an important determining factor in an individual's attitudes toward immigrants. In countries with longer histories of external immigration (and where there has been a long discussion/debate about immigration), the moreeducated tend to be more favourable toward external migration; in many of the countries without this history of immigration, the more educated tend to be more supportive of internal migration, but not external migration. This finding likely reflects the fact that individuals in the former group of countries have had little choice but to debate the issue of external migration and develop clear opinions, whereas the latter group of countries has not been forced to address the issue in the same way.

Finally, even simple prejudice, or dislike of a particular group (or more specifically, feeling disturbed by a particular group), follows a very predictable pattern. Individuals who are hostile toward other nationalities tend to be less favourable toward internal migration, and individuals who are hostile toward other races tend to be less favourable toward external migration. The implication of this finding is that being disturbed by individuals of other cultural 
backgrounds produces hostility toward allowing this group of people into the country, whereas

feeling disturbed by individuals with different physical features tends to produce hostility toward allowing people into the country from outside of the EC. In other words, hostility toward external immigration appears to be more racially motivated and hostility toward internal migration appears to be based on nationalism. 


\section{Methodological Appendix: Measures of Independent Variables}

Cognitive Mobilisation. Following the work of Gabel (1998) and Gabel \& Palmer (1995), the following question was used as the operationalisation of cognitive mobilisation: When you get together with friends, would you say you discuss political matters frequently, occasionally, or never?

Support for the EU. Taking everything into consideration, would you say that (OUR COUNTRY) has on balance benefited or not from being a member of the European Community?

Ideology. In political matters people talk of "the left" and "the right". How would you place yourself on this scale? (Respondent is shown a horizontal scale ranging from 1-10).

Education. How old were you when you finished full-time education. (Those who are still studying are given their current ages as their levels of education.)

Self-Interest: Financial Situation. We also need some information about the income of this household to be able to analyse the survey results for different types of households. Here is a list of income groups. (SHOW INCOME CARD **) Please count the total wages and salaries per month of all members of this household; all pensions and social insurance benefits; child allowances and any other income like rents, etc... Of course, your answer as all other replies in this interview will be treated confidentially and referring back to you or your household will be impossible. Please give me the letter of the income group your household falls into before tax and other deductions.

Postmaterialism. There is a lot of talk these days about what (OUR COUNTRY'S) goals should be for the next ten or fifteen years. On this card are listed some of the goals that different people say should be given top priority. Would you please say which one you yourself consider to be most important in the long run? And what would be your second choice?

1. Maintaining order in the country 
2. Giving the people more say in important government decisions

3. Fighting rising prices

4. Protecting freedom of speech

5. Don't know

Individuals who select items 2 and 4 are coded as "postmaterialist;" those selecting items 1 and 3 are coded as "materialists;" and those selecting a combination of the items were coded as "mixed." (See Inglehart 1990 for a summary of this measurement technique.)

Blatant Prejudice. Some people are disturbed by the opinions, customs and way of life of people different from themselves.

- Do you personally find the presence of people of another nationality, disturbing in your daily life?

- And do you find the presence of people of another race disturbing?

- And do you find the presence of people of another religion disturbing? 


\section{References}

Allport, G.W. (1954). The nature of prejudice. Garden City, NY: Doubleday Anchor Books.

Anderson, C.J. \& Reichert. M.S. (1996). Economic benefits and support for membership in the E.U.: a cross-national analysis. Journal of Public Policy 15:231-49.

Bobo, L. \& Licari, F.C. (1989). Education and political tolerance. Public Opinion Quarterly 53:283-308.

Bogdanor, V. (1989). Direct elections, representative democracy and European integration. Electoral Studies 8:205-216. (1986). The future of the European Community. Government and Opposition 21:161-176.

Cameron, D. (1991). The Single European Act and the 1992 Program. In Euro-politics: Institutions and Policy-Making in the New European Community, Alberta Sbragia, ed.

Citrin, J., Green, D.P., Muste, C. \& Wong, C. (1997). Public opinion toward immigration reform: the role of economic motivations. Journal of Politics 59:858-81.

Citrin, J., Reingold, B. \& Green, D.P. (1990). American identity and the politics of ethnic change. Journal of Politics 52:1124-54.

Clarke, H.D. \& Dutt, N. (1991). Measuring value change in western industrialized societies: the impact of unemployment. American Political Science Review 85:905-20.

Converse, P.E. (1975). Some mass-elite contrasts in the perception of political spaces. Social Science Information 14 (3/4):49-83.

. (1964). The nature of belief systems in mass publics. in: D.E. Apter (ed.), Ideology and discontent. New York: Free Press.

Cornelius, W.A., Martin, P.L. \& Hollifield, J.F., eds. (1994). Controlling immigration: a global perspective. Stanford: Stanford University Press.

Dinan, D. (1994). An ever closer union? Boulder, CO: Lynne Rienner Publishers.

Duch, R.M. \& Taylor, M.A. (1993). Postmaterialism and the economic condition. American Journal of Political Science 37:747-79.

van der Eijk, C. \& Franklin, M.N. (1996). Choosing Europe? the European electorate and national politics in the face of union. University of Michigan Press.

Esser, H. \& Korte, H. (1985). Federal Republic of Germany. in: T. Hamar (ed.), European immigration 
policy: a comparative study. Cambridge: Cambridnge University Press.

Flanagan, S.C. (1987). Changing values in industrial societies revisited: towards a resolution of the values debate. American Political Science Review 81:1303-19.

Franklin, M.N., Mackie, T.T. \& Valen, H., eds . (1992). Electoral change: responses to evolving social and attitudinal structures in western countries. Cambridge: Cambridge University Press.

Franklin, M.N., Marsh, M. \& McLaren. L.M. (1994). Uncorking the bottle: popular opposition to European unification in the wake of Maastricht. Journal of Common Market Studies 32: 455-72.

Gabel, M. (1998). Public support for European integration: an empirical test of five theories. Journal of Politics 60:333-54.

Gabel, M. \& Palmer, H.D. (1995). Understanding variation in public support for European integration. European Journal of Political Research 27:3-19.

Gibson, J.L. \& Caldiera, G. (1995). The legitimacy of transnational legal institutions: compliance, support, and the European Court of Justice.” American Journal of Political Science 39:459-489.

Hammar, T. (1985). Introduction. in: T. Hammar (ed.) European immigration policy: a comparative study. Cambridge: Cambridge University Press.

Hobsbawm, E.J. (1990). Nations and nationalism since 1780. Cambridge: Cambridge University Press.

Hollifield, J.F. (1994). The migration crisis in Western Europe: the search for a national model. Presented at the Annual Meeting of the American Political Science Association, New York.

Hoskin, M. (1991). New immigrants and democratic society: minority integration in western democracies. New York: Praeger.

Huber, J. \& Inglehart, R. (1995). Expert interpretations of party space and party locations in 42 societies. Party Politics 1:73-111.

Inglehart, R. (1970). Cognitive mobilization and European identity. Comparative Politics 3:45-70.

Inglehart, R. (1977). The silent revolution: changing values and political styles among western publics. Princeton, NJ: Princeton University Press.

Inglehart, R. (1990). Culture shift in advanced industrial society. Princeton, NJ: Princeton University Press.

Inglehart, R. \& Klingemann, H.D. (1979). Ideological conceptualization and value priorities. in: S. Barnes 
\& M. Kaase (eds.), Political action: mass participation in five western democracies. Beverly Hills: Sage.

Inglehart, R. (1976). Party identification, ideological preference and the left-right dimension among western mass publics. in: I. Budge, I. Crewe \& D. Farlie (eds.), Party identification and beyond. London: John Wiley and Sons.

Janssen, J.H. (1991). Postmaterialism, cognitive mobilization and public support for European integration. British Journal of Political Science 21:443-68.

Kinder, D.R. \& Sears, D.O. (1981). Prejudice and politics: symbolic racism versus racial threats to the good life. Journal of Personality and Social Psychology 40:414-31.

Knigge, P. (1998). The ecological correlates of right-wing extremism in Western Europe. European Journal of Political Research 34:249-79.

Knutsen, O. (1998). Expert judgements of the left-right location of political parties: a comparative longitudinal study. West European Politics 21:63-94.

Lau, R.R., Brown, T.A. \& Sears, D.O. (1978). Self-interest and civilians' attitudes toward the Vietnam War. Public Opinion Quarterly 42:464-83.

Lewis-Beck, M.S. \& Mitchell, G.E. (1993). French electoral theory: the National Front test. Electoral Studies 12:112-27.

Martin, P.L. (1994). Germany: reluctant land of immigration. in: W.A. Cornelius, P.L. Martin \& J.F. Hollifield (eds.), Controlling immigration: a global perspective. Stanford: Stanford University Press.

Martiniello, M. (1995). European citizenship, European identity and migrants: towards the post-national state? in: R. Miles \& D. Thränhardt (eds.), Migration and European integration: the dynamics of inclusion and exclusion. London: Pinter Publishers.

McLaren, L.M. (1996a). Individual and contextual explanations of support for the rights of immigrants in Western Europe. PhD Thesis.

McLaren, L.M. (1996b). Citizen support for migrants in Western Europe: individual and contextual explanations." Paper presented at the Annual Meeting of the Midwest Political Science Association, Chicago. 
McLaren, L.M. (1999). Explaining right-wing violence in Germany: a time series analysis. Social Science Quarterly, forthcoming.

New York Times, various issues.

Nunn, C.Z., Crockett, H.J. \& J. A. Williams. (1978). Tolerance for nonconformity. San Francisco: JosseyBass.

Quillian, L. (1995). Prejudice as a response to perceived group threat: population composition and antiimmigrant and racial prejudice in Europe. American Sociological Review 60:586-611.

Sears, D.O., Hensler, C. P. \& Spear, L.K. (1977). Opposition to bussing: self-interest or symbolic racism? American Political Science Review 369-384.

Sears, D.O., Tyler, T.R., Citrin, J. \& Kinder, D.R. (1978). Political system support and public response to the 1974 energy crisis. American Journal of Political Science 22:56-82.

Stouffer, S.A. (1955). Communism, conformity, and civil liberties. Garden City, NJ: Doubleday.

Sullivan, J.L., Piereson, J. \& Marcus, G.E. (1982). Political tolerance and American democracy. Chicago: University of Chicago Press.

Thränhardt, D. \& Miles, R. (1995). Introduction: European integration, migration and processes of inclusion and exclusion. in: R. Miles \& D. Thränhardt (eds.), Migration and European integration: the dynamics of inclusion and exclusion. London: Pinter Publishers.

Urwin, D. (1995). The community of Europe. London: Longman.

Wessels, B. (1995). Evaluations of the EC: elite or mass-driven? in: O. Niedermayer \& R. Sinnott (eds.) Public opinion and internationalized governance, eds.. Oxford: Oxford University Press.

Zaller, J. (1992). The nature and origins of mass opinion. New York: Cambridge University Press.

Zaller, J. (1991). Information, values, and opinion. American Political Science Review 85:1215-37.

Zaller, J. (1990). Political awareness, elite opinion leadership, and the mass survey response. Social Cognition 8:125-53. 
Table 1. Treatment of EC Immigrants versus non-EC immigrants (percentages)

\begin{tabular}{|c|c|c|c|c|c|c|c|}
\hline Country & $\frac{\text { Medit Not }}{\text { Accepted }}$ & $\frac{\frac{\text { Medit }}{\text { Accepted }}}{\underline{\text { No }}}$ & $\frac{\text { EC Not }}{\underline{\text { Accepted }}}$ & $\frac{\underline{E C}}{\frac{\text { Accepted }}{\text { No }}}$ & 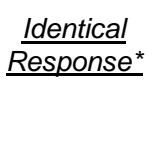 & $\frac{\frac{\text { More }}{\text { Favorable }}}{\text { Toward EC }}$ & Total N \\
\hline France & 38 & $\frac{10}{10}$ & 20 & 30 & 58 & 36 & 1019 \\
\hline Belgium & 33 & 11 & 17 & 33 & 56 & 38 & 1022 \\
\hline Netherlands & 23 & 12 & 16 & 29 & 67 & 27 & 1004 \\
\hline W. Germany & 24 & 17 & 15 & 32 & 59 & 30 & 1036 \\
\hline Italy & 18 & 23 & 11 & 48 & 65 & 31 & 1039 \\
\hline Luxembourg & 19 & 9 & 10 & 18 & 77 & 19 & 513 \\
\hline Denmark & 31 & 6 & 7 & 41 & 47 & 51 & 1000 \\
\hline Ireland & 14 & 22 & 6 & 51 & 63 & 33 & 1008 \\
\hline Britain & 28 & 8 & 20 & 29 & 64 & 31 & 1073 \\
\hline N. Ireland & 17 & 19 & 13 & 32 & 73 & 22 & 306 \\
\hline Greece & 32 & 10 & 19 & 29 & 68 & 29 & 1003 \\
\hline Spain & 14 & 27 & 5 & 57 & 62 & 35 & 1022 \\
\hline Portugal & 11 & 26 & 6 & 53 & 69 & 28 & 1000 \\
\hline E. Germany & 36 & 10 & 22 & 23 & 66 & 28 & 1064 \\
\hline
\end{tabular}

*Percent giving identical responses to questions about allowing entry of immigrants from outside the EC and allowing entry of immigrants from inside the EC.

${ }^{* *}$ Percent that gave more favorable responses to questions about entry for immigrants from within the EC than for immigrants from outside the EC.

Note: Percentages do not total to 100 within each category in the last two columns because there was a small number of individuals $(<4 \%$ in all countries) who were more favorable toward those coming from outside of the EC than those coming from within the EC. 
Table 4. Importance of Xenophobia in Dividing the Left from the Right

\begin{tabular}{lc} 
Country & Percent of Experts Claiming \\
\cline { 2 - 2 } France & $11 \%^{*}$ \\
Belgium & $15 \%^{*}$ \\
Netherlands & $10 \%^{*}$ \\
West Germany & $24 \%^{*}$ \\
Italy & $16 \%^{*}$ \\
Denmark & $0 \%^{*}$ \\
Ireland & $0 \%$ \\
Great Britain & $2 \%$ \\
Northern Ireland & $2 \%$ \\
Spain & $0 \%{ }^{*}$ \\
Portugal & $0 \%$ \\
East Germany & $24 \%{ }^{*}$
\end{tabular}

Figures are reported in Knutsen (1998).

* indicates that the left-right self-placement coefficient was significant in Table 2.

** The percentage for Portugal was not available in the Knutsen (1998) article, but was inferred based on the fact that immigration still had not become a divisive issue in Portugal by 1993. 